\title{
Seasonal Variation and Bacteriological Pollution of River Amba of Nasarawa State, Nigeria
}

\author{
M. K. Haruna ${ }^{1, *}$, T. A Olusi ${ }^{2}$, A. S. Wali ${ }^{1}$ \\ ${ }^{1}$ Department of Farming System Research, Lake Chad Research Institute, \\ P.M.B. 1293 Maiduguri, Nigeria \\ *Telephone: +2348036774827 \\ ${ }^{2}$ Department of Biological Science, Federal University of Technology, \\ P.M.B. 704, Akure, Nigeria \\ *E-mail address: mokharry2002@yahoo.com
}

\begin{abstract}
The quality of Amba River in Nasarawa State in the North Central Nigeria was investigated for a period of one year covering dry and rainy season. Water samples were collected from four different locations (Gandu, Wadatan-Waje, Kofan-Kaura and Unguwan-Galadima) along the river course and analyzed for Bacteriological parameter, using standard methods. The results indicated seasonal variation in coliform population with higher values at Wadatan-waje and Unguwan-galadima during rainy season. The values obtained for coliform on the average for the two seasons were beyond the maximum acceptable standard set by the World Health Organization (WHO, 2004) for drinking water. Thus, settlers along the River should be enlightened on the danger of consuming untreated water from the River. Also, measures at regulating the pollution of the River should be taken for a healthy and vibrant community.
\end{abstract}

Keywords: coliform; pollution; River Amba

\section{INTRODUCTION}

The scarcity of clean water and pollution of fresh water has led to a situation in which one-fifth of the urban dwellers in developing countries and three quarters of their rural counterparts do not have access to reasonable safe water supplies (Lloyd and Helmer, 1992). For example in Nigeria, it is estimated that only $48 \%$ of the inhabitants of the urban and semi urban areas and $29 \%$ of rural areas inhabitants have access to potable water supply (Federal Republic of Nigeria, 2000). The over production of higher trophic levels biomass and the subsequent decay of dead plant could lead to oxygen depletion, death of aquatic organisms and development of anaerobic zone where bacterial action produces foul odour and bad tastes (EPA, 1976; Sahu, 2014)

The common practice of unregulated waste disposal into water courses can affect their normal use by municipalities. Aquatic environments near cities are usually prone to over loading with a variety of pollutants either through direct or indirect discharges. This situation may be worsened by the indiscriminate disposal of untreated wastes, often heavily laden with sewage into actively used streams (Owa, 2014). The public health arising from faecal 
pollution of natural waters has been documented by several workers (Owa, 2014; Sahu, 2014).

Aside from human health concerns, the Indiscriminate dumping of waste into natural water bodies can over task the self purifying capacity of the receiving water, this will not only endanger the resident aquatic life but may also impair other amenity purposes and non consumption uses that the river course might be put into (Vijayalakshmi et al., 2013). In view of the foregoing, there is the need to assess the quality of the River Amba as it serve as alternative source of water to settlements along the river. This study was conducted with the objective to determine the coliform population of the River Amba.

\section{METHODOLOGY}

The study was carried out in River Amba (Long. 8 28'60' Lat. $8^{\circ} 28^{\prime} 0^{\prime}$ ' and altitude $295 \mathrm{~m}$ ) located in Lafia the capital of Nasarawa State of Nigeria. The River was chosen because it serves as source to the state water board who supply water to the inhabitants of Lafia and its environs. It has a temperature of $26^{\circ} \mathrm{C}$ to $30^{\circ} \mathrm{C}$, rainfall of $1120 \mathrm{~mm}$ to 1500 $\mathrm{mm}$, relative humidity of $60-80 \%$ and falls within the guinea savanna vegetation (www.gatemap.net, 2014). Sampling locations were Gandu, Wadatan-Waje, Kofan-Kaura and Ungwan-Galadima. Samples were collected on monthly basis from these settlements throughout the rainy and dry seasons (May to October, 2007 and November, 2007 to April, 2008). Bacteriological analysis was done using the Most Probable Number (Multiple Tube Method) (APHA, 1999) (Figure 1).

The water sample was mixed with a nutrient medium, Mac Conkey broth and was incubated for 24 hours at a temperature of $37^{\circ} \mathrm{C}$ for total coliform count. The production of acid which turned the purple MacConkey broth yellow and gas which was caught in a small inverted tube (Durhm's tube) are confirmation of coliform bacteria in the water sample. A number of test tube were incubated containing different volumes of the water under examination and by observing the number of positive reactions (Production of both acid and gas) it was possible to count the Most Probable Number (MPN) of coliform bacteria in the original water samples with Suntex 560 colony counter. The results were expressed as Coliform Forming Units/100 $\mathrm{ml}(\mathrm{CFU} / 100 \mathrm{ml})$ of water. The data obtained were analysed using Statistix 8.0 to determine the respective mean, standard deviation and coefficient of variability values for the rainy and dry seasons.

\section{RESULTS AND DISCUSSION}

Tables 1 and 2 show the mean, standard deviation, and coefficient of variation (cv) of coliform bacteria (CFU/100 ml) of four locations of River Amba during the rainy and dry seasons. The coliform population ranged from 8.17-24.17 and 6.0-26.174 CFU/100 ml during the rainy and dry seasons, respectively. The result shows seasonal variation of total coliform in River Amba. The seasonal variations of total coliform in River Amba revealed higher values at Wadatan-waje and Unguwan-galadima during rainy season. 


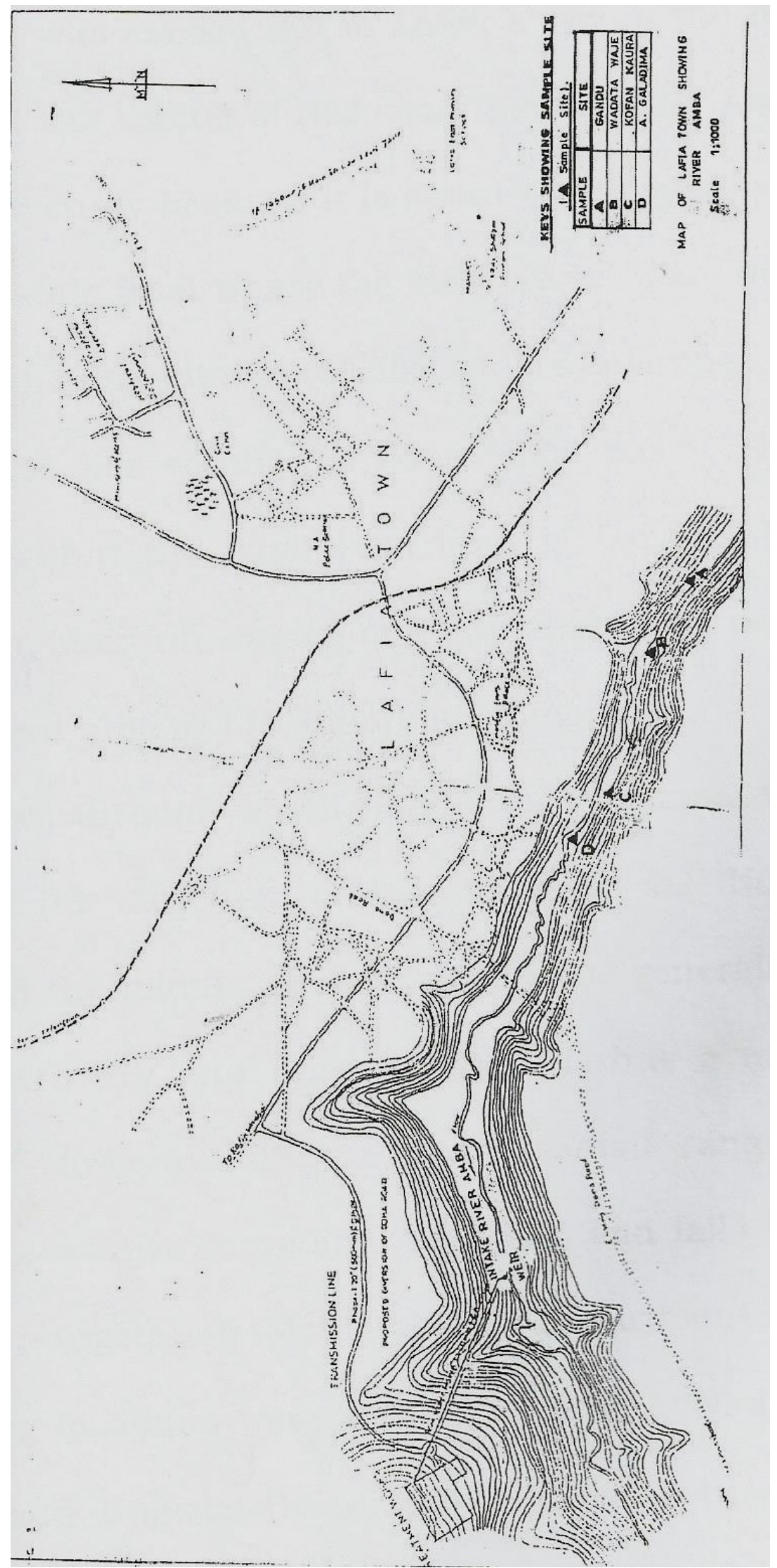

Figure 1. Map of River Amba ampling locations (ABCD). 
The high population during rainy season might be as a result of indiscriminate dumping of waste and human faeces passed around the river bank which were washed into the river during rains. This collaborates studies of (Venkatesraju et al. 2010; Mishra and Triphathi, 2007). Similarly, the high total coliform counts in the water body may also be as a result of contributions from the tributaries. This agrees with earlier studies of (Maitera and Sudi, 2011). Conversely, Gandu and Kofan-kaura locations had higher coliform values during the dry season. This is in contrast with earlier studies in which higher accumulation of coliform are recorded during rainy season. The direct dumping of refuse and other pollutants and their accumulation might be the reason for high coliform concentrations in these locations which are diluted by rain fall and flow away to Doma axis. The values for coliform population from this study are higher than the WHO (2006) and NAFDAC (2001) recommended standards. Hence, there is the need for institutional reforms and review of policy targets as well as provide some guidelines as suggested by (Nwankwoala, 2014). Similarly, the results generally revealed that the portions of River Amba assessed in this work were within safe limits for irrigation and fishing activities but not for direct domestic utilization.

Table 1. Bacteriological (CFU/100 ml) quality of surface water of Amba River during rainy season from four locations.

\begin{tabular}{|c|c|c|c|}
\hline Location & Mean & Standard deviation & $\begin{array}{c}\text { Coefficient of } \\
\text { variation }\end{array}$ \\
\hline Gandu & 13.83 & 13.69 & 98.99 \\
\hline Wadatan- waje & 16.33 & 21.47 & 131.48 \\
\hline Kofan-kaura & 24.17 & 21.47 & 87.59 \\
\hline Unguwan-galadima & 8.17 & 6.01 & 73.56 \\
\hline
\end{tabular}

Table 2. Bacteriological (CFU/100 ml) quality of surface water of Amba River during dry season from four locations.

\begin{tabular}{|c|c|c|c|}
\hline Location & Mean & Standard deviation & $\begin{array}{c}\text { Coefficient of } \\
\text { variation }\end{array}$ \\
\hline Gandu & 21.0 & 12.41 & 59.38 \\
\hline Wadatan- waje & 14.95 & 13.38 & 90.22 \\
\hline Kofan-kaura & 26.17 & 3.82 & 14.60 \\
\hline Unguwan-galadima & 6.0 & 2.53 & 42.17 \\
\hline
\end{tabular}

\section{CONCLUSION}

The result obtained from the study indicates that there was seasonal variation in the coliform bacteria concentration and exceeds the WHO acceptable standard of drinking water, hence this poses a health risk to several inhabitants who rely primarily on the river as their 
source of domestic water. There is the need to enlighten settlers along the River on the danger of consuming untreated water from the River. Also, measures at regulating the pollution of the River should be taken by the government, traditional rulers, civil society groups and individuals for a healthy and vibrant community.

\section{ACKNOWLEDGEMENT}

The authors acknowledge the Environmental Sanitation Authority Laboratory and the Department of Biological Science University of Agriculture all at Makurdi, Benue State, Nigeria for assisting in the bacteriological analysis.

\section{References}

[1] APHA. "Standard methods for the examination of water and wastewater, 17th edition", American Public Health Association, Washington, DC, 1989.

[2] EPA (1976). Environmental Protection Agency. Quality criteria for water use, EPA, 440, 1a-76.013 Environmental Agency, Washington.

[3] FGN (2000). National Water Supply and Sanitation Policy. Department of Water Supply and Quality Control, Federal Ministry of Water Resources. Federal Republic of Nigeria.

[4] Lloyd B., Helmer R., (1992). Surveillance of drinking water quality in rural area. Longman Scientific and Technical Publication. New York, Wiley, 34-56.

[5] Maitera O.N., I.Y. Sudi, Advances in applied science research 2(3) (2011) 191-197.

[6] Mishra Archana, B.D. Tripathi, Current World Enviroment 2(2) (2007) 149-154.

[7] NAFDAC (2001) NAFDAC Consumer Bulletin Oct.- Dec., 20011 (9), 87-89

[8] Nwankwoala H. O., International Letters of Natural Sciences 9 (2014) 12-25.

[9] Owa F. W., International Letters of Natural Sciences 3 (2014) 1-6.

[10] Sahu Omprakash, International Letters of Natural Sciences 8(1) (2014) 1-8.

[11] Venkateshraju K., Ravikuamr P., Soma Shankar R.K., Prakash K.L., Journal of science and engineering and technology 6(1) (2010) 50-59.

[12] Vijayalakshmi G., Ramadas V., H. Nellaiah, International Journal of Research in Engineering and Technology 2(3) (2013) 305-312.

[13] WHO (2006). Guideline for drinking water quality, First addendum to the Third Edition, 1; 491-493.

[14] www.gatemap.net/map/nigeria/nigeria_(general)/_amba_river/ (2014) retrieved $14^{\text {th }}$ April, 2014. 